Marquette University

e-Publications@Marquette

College of Nursing Faculty Research and

Publications

Nursing, College of

$7-1-2016$

Nurses' Own Birth Experiences Influence Labor
Support Attitudes and Behaviors

Ann P. Aschenbrenner

Columbia College of Nursing

Lisa Hanson

Marquette University, lisa.hanson@marquette.edu

Teresa S. Johnson

University of Wisconsin - Milwaukee

Sheryl Talcott Kelber

University of Wisconsin - Milwaukee

Accepted version. Journal of Obstetric, Gynecologic, \& Neonatal Nursing, Vol. 45, No. 4 (July-August 2016): 491-501. DOI. (C) 2016 AWHONN, the Association of Women's Health, Obstetric and Neonatal Nurses. Used with permission. 


\title{
Nurses' Own Birth Experiences Influence Labor Support Attitudes and Behaviors
}

\author{
Lisa Hanson \\ College of Nursing, Marquette University \\ Milwaukee, WI
}

Ann P. Aschenbrenner

College of Nursing, University of Wisconsin Milwaukee

Milwaukee, WI

Teresa S. Johnson

College of Nursing, University of Wisconsin Milwaukee Milwaukee, WI

\section{Sheryl Talcott Kelber}

College of Nursing, University of Wisconsin Milwaukee

Milwaukee, WI

[Journal of Obstetric Gynecologic \& Neonatal Nursing, Vol 45, No. 4 (July-August 2016): pg. 491-501. DOI. This article is (C) AWHONN, the Association of Women's Health, Obstetric and Neonatal Nurses.] and permission has been granted for this version to appear in e-Publications@Marquette. [AWHONN, the Association of Women's Health, Obstetric and Neonatal Nurses.] does not grant permission for this article to be further copied/distributed or hosted elsewhere without the express permission from [AWHONN, the Association of Women's Health, Obstetric and Neonatal Nurses.].] 
NOT THE PUBLISHED VERSION; this is the author's final, peer-reviewed manuscript. The published version may be accessed by following the link in the citation at the bottom of the page.

\section{Abstract:}

Objective: To describe the attitudes of intrapartum nurses about the importance of and intent to provide professional labor support (PLS); barriers to PLS, such as perceived subjective norms and perceived behavioral control; and relationships among attitudes, behaviors, and nurse and site characteristics.

Design: A cross-sectional, mixed-methods, descriptive design was guided by the Theory of Planned Behavior.

Setting: Three hospital sites in one region of a single Midwestern state.

Participants : Sixty intrapartum nurses participated.

Methods: The Labor Support Questionnaire and demographic questionnaire were administered online. The Labor Support Questionnaire is used to measure attitudes about the importance of and intended behaviors associated with labor support.

Results: Nurse Caring Behaviors was the highest rated PLS dimension. Participants' own personal birth experiences and length of current intrapartum experience were positively correlated with attitudes about and intent to provide PLS. Barriers to PLS included staffing, documentation, physicians, use of epidural analgesia, doulas, and birth plans.

Conclusion: Personal birth and work experience influenced attitudes about and intent to provide PLS and demonstrated the relationships described in the Theory of Planned Behavior. Intrapartum nurses may benefit from an examination of their personal experiences to see how they might influence attitudes about PLS. Enhanced training and expanded labor and birth experience for novice nurses or students may improve attitudes and intended behavior with regard to PLS. Further investigations of the factors that affect integration of PLS into care are important to promote healthy birth outcomes.

Keywords: attitudes, barriers, behaviors, intrapartum, professional labor support

Women need physical and emotional support during the intense and profound experiences of labor and birth. Friends, family members, doulas, midwives, or nurses can provide this support. Most U.S. women give birth in hospitals (MacDorman, Mathews, \& Declercq, 2014), and historically labor support has been an important role of labor and delivery nurses. Outcomes

[Journal of Obstetric Gynecologic \& Neonatal Nursing, Vol 45, No. 4 (July-August 2016): pg. 491-501. DOI. This article is @ AWHONN, the Association of Women's Health, Obstetric and Neonatal Nurses.] and permission has been granted for this version to appear in e-Publications@Marquette. [AWHONN, the Association of Women's Health, Obstetric and Neonatal Nurses.] does not grant permission for this article to be further copied/distributed or hosted elsewhere without the express permission from [AWHONN, the Association of Women's Health, Obstetric and Neonatal Nurses.].] 
NOT THE PUBLISHED VERSION; this is the author's final, peer-reviewed manuscript. The published version may be accessed by following the link in the citation at the bottom of the page.

related to the use of professional labor support (PLS) include women's increased satisfaction with care ( reported decreased oxytocin use (Gagnon, Waghorn, \& Covell, 1997) and fewer cesarean births (Gagnon \& Waghorn, 1999) with PLS, these results were not statistically significant. Nursing care has been shown to have a statistically significant independent influence on cesarean birth rates (Radin, Harmon, \& Hanson, 1993). Despite these benefits, PLS has not been found to lead to the outcomes found in studies of nonprofessional labor support provided by untrained laypersons, trained doulas, or midwives ( Gates, Hofmeyr, \& Sakala, 2013).

Researchers found that lay support was associated with fewer cesarean births (Klaus, Kennell, Robertson, \& Sosa, 1986; Madi, Sandall, Bennett, \& MacLeod, 1999; Morhason-Bello, Adedokun, Ajengbede, Olayemi, Oladokun, \& Fabamwo, 2009) , shorter duration of labor (Klaus et al., 1986; Morhason-Bello et al., 2009), less use of oxytocics (Klaus et al., 1986; Madi et al., 1999), and less use of analgesia (Madi et al., 1999). Similar results were documented in studies of trained labor support, including shorter labors (Campbell, Lake, Falk, \& Backstrand, 2006; Kashanian, Javadi, \& Haghighi, 2010; Kennell, Klaus, McGrath, Robertson, \& Hinkley, 1991; Langer, Campero, Garcia, \& Reynoso, 1998), fewer cesareans (Kashanian et al., 2010; Kennell et al., 1991; McGrath \& Kennell, 2008; Trueba, Contreras, Velazco, \& Lara, 2000), fewer epidurals (Kennell et al., 1991; McGrath \& Kennell, 2008), and less use of analgesia (Hodnett \& Osborn, 1989) and oxytocics (Hodnett \& Osborn, 1989; Trueba et al., 2000). These studies were conducted primarily outside the United States at sites at which usual care involved crowded labor rooms and little or no support.

Reported benefits of professional labor support include increased maternal satisfaction; nonprofessional labor support is associated with shorter labor, fewer cesareans, and fewer epidurals.

In contrast to lay support, PLS primarily occurs in an intrapartum hospital setting. A number of personal and environmental factors have been studied for their effects on PLS. Work demands such as hospital unit staffing were negatively related to PLS (Carlton, Callister, Christiaens, \& Walker, 2009; Davies \& Hodnett, 2002). Subjective norms, that is, a person's beliefs that others value a behavior, may also influence behavior (Ajzen, 2002). A contemporary example of how subjective norms may influence PLS involves the prevalence of the use of epidural analgesia in hospitals, and the intent of nurses to provide continuous labor support differs depending on epidural use (Payant, Davies, Graham, Peterson, \& Clinch, 2008). Professional labor support for women who have epidural analgesia may not be socially

[Journal of Obstetric Gynecologic \& Neonatal Nursing, Vol 45, No. 4 (July-August 2016): pg. 491-501. DOI. This article is @ AWHONN, the Association of Women's Health, Obstetric and Neonatal Nurses.] and permission has been granted for this version to appear in e-Publications@Marquette. [AWHONN, the Association of Women's Health, Obstetric and Neonatal Nurses.] does not grant permission for this article to be further copied/distributed or hosted elsewhere without the express permission from [AWHONN, the Association of Women's Health, Obstetric and Neonatal Nurses.].] 
NOT THE PUBLISHED VERSION; this is the author's final, peer-reviewed manuscript. The published version may be accessed by following the link in the citation at the bottom of the page.

supported by staff on an intrapartum unit (Carlton et al., 2009; Payant et al., 2008), and researchers suggested that the prevalence of the use of epidural analgesia jeopardizes nurses' abilities to remain current in labor support skills (Carlton et al., 2009). Nurses may find it difficult to maintain knowledge and expertise for labor support when women do not often give birth naturally without epidural analgesia.

Nurses also were influenced by managerial or unit-based views on PLS (Angus, Hodnett, \& O'Brien-Pallas, 2003; Miltner, 2002; Sleutel, Schultz, \& Wyble, 2007). In addition, attitudes about labor support practices (Davies \& Hodnett, 2002; Sauls, 2007), facility culture (Sleutel et al., 2007), and relationships with physicians (Angus et al., 2003; Carlton et al., 2009; Sleutel, 2000; Sleutel et al., 2007) also were reported to influence PLS. For example, nurses frequently viewed the labor-controlling behaviors of physicians, such as offering epidural analgesia and augmenting and monitoring labor, as limiting their ability to provide appropriate care for women in labor (Angus et al., 2003; Sleutel, 2000; Sleutel et al., 2007). Miltner's (2002) observational study of intrapartum nursing care showed that nurses' actions focused on the family and on patient education unrelated to the labor process, rather than on the promotion of labor progress or the woman's comfort. This lack of focus on actions to promote labor progress and comfort may provide a plausible explanation for a dearth of positive outcomes related to PLS.

In addition, nurses' ages and experience were directly related to the time they spent in the provision of labor support (Barrett \& Stark, 2010). Older nurses and those with more PLS experience showed more confidence and competence in the provision of PLS than younger, less-experienced nurses (Barrett \& Stark, 2010). Nurses with more experience in PLS provided more coping alternatives to women during labor (Sleutel et al., 2007). To our knowledge, the relationship between nurses' own personal birth experiences and PLS has not been reported in the literature.

Although the intrapartum environment; nurse characteristics and attitudes; subjective norms; and managerial, peer, and physician support may influence PLS, to our knowledge investigators have not evaluated the interactions of these factors and their effect on labor and birth outcomes. The objective of our study was to describe intrapartum nurses' attitudes about and intent to provide PLS; to describe barriers to PLS, such as perceived subjective norms and perceived behavioral control; and to identify relationships among attitudes, behaviors, and nurse and site characteristics.

[Journal of Obstetric Gynecologic \& Neonatal Nursing, Vol 45, No. 4 (July-August 2016): pg. 491-501. DOI. This article is @ AWHONN, the Association of Women's Health, Obstetric and Neonatal Nurses.] and permission has been granted for this version to appear in e-Publications@Marquette. [AWHONN, the Association of Women's Health, Obstetric and Neonatal Nurses.] does not grant permission for this article to be further copied/distributed or hosted elsewhere without the express permission from [AWHONN, the Association of Women's Health, Obstetric and Neonatal Nurses.].] 
NOT THE PUBLISHED VERSION; this is the author's final, peer-reviewed manuscript. The published version may be accessed by following the link in the citation at the bottom of the page.

\section{Conceptual Framework}

The conceptual framework for this study was adapted from the Theory of Planned Behavior (Ajzen, 2002). According to this theory, actual behavior depends on the intent to act, which is determined by attitudes, subjective norms, and perceived behavioral control related to the behavior. Attitudes are an individual's tendency to respond in a negative, neutral, or positive manner. Subjective norms (beliefs that a behavior is valuable to others) and perceived behavioral control (i.e., perception of factors that may promote or impede a behavior) also influence behavioral intent. Subjective norms may be described as social pressure to perform or not perform the behavior.

Attitudes, subjective norms, and perceived behavioral control may be influenced by personal beliefs that result from an individual's experiences and unique characteristics. Examples of these include age, gender, ethnicity, education, past experiences, and exposure to information (Ajzen, 2002; Ajzen \& Fishbein, 1980). Positive attitudes toward a behavior, belief that the behavior is possible to complete, and perception that colleagues and persons in authority value the behavior are associated with promoting behavioral intent. In contrast, negative attitudes and perception of barriers, such as lack of perceived behavioral control or negative subjective norms, diminish behavioral intent. The intent to act is the strongest predictor of the actual behavior (Ajzen, 2002; Ajzen \& Fishbein, 1980).

\section{Methods}

\section{Design}

A cross-sectional, mixed-method, descriptive study was conducted at three intrapartum hospital sites in Midwestern U.S. communities during a 2-month period in 2012. Rural, suburban, and urban sites were selected to capture data from nurses in diverse settings. The quantitative findings of the study are reported herein.

\section{Setting and Sample}

A total of 60 nurses participated in this study. The rural Level 1 hospital employed 16 nurses and had a total of 722 births per year, $17 \%$ of which were attended by a single certified nurse-midwife (CNM). No data were available on frequency of doula support. The suburban Level 2 hospital employed 24 nurses and had a total of 682

[Journal of Obstetric Gynecologic \& Neonatal Nursing, Vol 45, No. 4 (July-August 2016): pg. 491-501. DOI. This article is (C) AWHONN, the Association of Women's Health, Obstetric and Neonatal Nurses.] and permission has been granted for this version to appear in e-Publications@Marquette. [AWHONN, the Association of Women's Health, Obstetric and Neonatal Nurses.] does not grant permission for this article to be further copied/distributed or hosted elsewhere without the express permission from [AWHONN, the Association of Women's Health, Obstetric and Neonatal Nurses.].] 
births per year, none attended by CNMs, and $10.85 \%$ supported by doulas. The urban Level 3 hospital employed 65 nurses and had a total of 3,100 births a year, $25 \%$ of which were attended by CNMs, with no data available on frequency of doula support. Epidural rates were $53 \%, 58 \%$, and $50 \%$ respectively. Total cesarean rates varied from $21 \%$ to $25 \%$, and forceps-assisted birth rates varied from less than $0.08 \%$ to $2.00 \%$ among the hospitals.

\section{Procedures}

\section{Demographic questionnaire}

Participants completed a demographic questionnaire that solicited information about professional and personal characteristics that may influence nurses' attitudes and behaviors about labor support to allow comparisons across the three hospital settings. These characteristics included items identified as influential in the Theory of Planned Behavior, such as participants' ages; highest nursing degree; total length of nursing experience; length of time on the current labor and delivery unit; and personal birth experiences, including whether or not they experienced labor, mode of delivery (vaginal or cesarean), and use of an epidural or nonepidural analgesic or only nonpharmaceutical therapies for pain management. These factors and their relationships to constructs from the Theory of Planned Behavior are displayed in Figure 1.

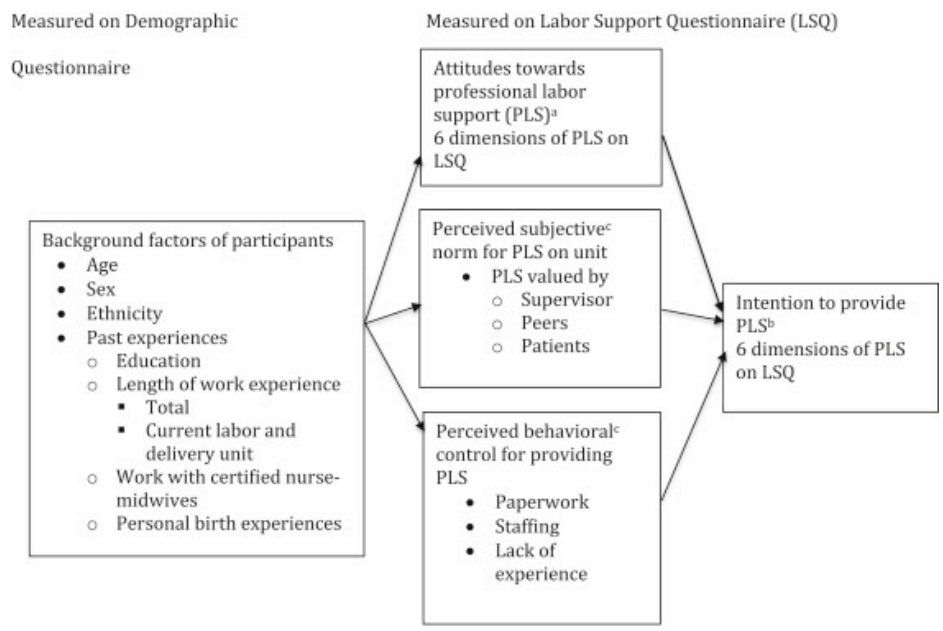

Figure 1. Schematic presentation of conceptual framework based on the Theory of Planned Behavior, "Perceived Behavioral Control, Self-Efficacy,

[Journal of Obstetric Gynecologic \& Neonatal Nursing, Vol 45, No. 4 (July-August 2016): pg. 491-501. DOI. This article is @ AWHONN, the Association of Women's Health, Obstetric and Neonatal Nurses.] and permission has been granted for this version to appear in e-Publications@Marquette. [AWHONN, the Association of Women's Health, Obstetric and Neonatal Nurses.] does not grant permission for this article to be further copied/distributed or hosted elsewhere without the express permission from [AWHONN, the Association of Women's Health, Obstetric and Neonatal Nurses.].] 
NOT THE PUBLISHED VERSION; this is the author's final, peer-reviewed manuscript. The published version may be accessed by following the link in the citation at the bottom of the page.

Locus of Control, and the Theory of Planned Behavior," by I. Ajzen, 2002, J ournal of Applied Social Psychology, 32, 665-683. ${ }^{a}$ Measured on LSQ Part 1. bMeasured on LSQ Part 2. 'Measured on LSQ Part 3.

\section{Labor Support Questionnaire}

The Labor Support Questionnaire (LSQ; Sauls, 2000, 2004a, 2007) was based on the Theory of Planned Behavior (Ajzen, 2002). The questions in the LSQ address six dimensions of PLS behaviors for attitudes toward the importance of the behavior and the intention to perform those behaviors. Definitions of terms and PLS dimensions are presented in Table 1. For Attitudes Toward Importance and Behavioral Intent, participants rated each item on a 6-point Likert-type scale (range, 0-5) in which higher ratings indicate more importance of or greater intent to use the behavior. The items are grouped into six dimensions of PLS (27 items): (a) Tangible Support (6 items); (b) Advocacy ( 5 items); (c) Emotional Support (ES)-Reassurance (5 items); (d) ES-Creating Control, Security, Comfort (5 items); (e) ES-Nurse Caring Behaviors ( 3 items); and (f) I nformational Support ( 3 items); these have been previously reported by Sauls (2004a, 2004b, 2006). Dimension scores for importance and intention are computed using the mean of the ratings of all items in each dimension. Possible scores for each dimension range from 0 to 5. Sauls (2004a) reported Cronbach's alpha reliability for the LSQ. The alpha for Attitudes Toward I mportance was .92, and the alphas for the six dimensions ranged from .67 to .90; Informational Support and ESReassurance were both less than .70. For attitudes toward intention, the alpha was .86, and the alphas for the six dimensions ranged from .53 to .89; ES-Reassurance and ES-Nurse Caring Behaviors were both less than .70.

Table 1. Definition of Terms From the LSQ

\begin{tabular}{|c|c|c|}
\hline Term & Conceptual Definition & $\begin{array}{l}\text { Operational Definition } \\
\text { (Derived From the LSQ) }\end{array}$ \\
\hline PLS & $\begin{array}{l}\text { A deliberate interaction } \\
\text { between the intrapartum } \\
\text { nurse and the laboring } \\
\text { woman that supports the } \\
\text { woman to cope during } \\
\text { labor and birth. }\end{array}$ & $\begin{array}{l}\text { The score on LSQ Parts } 1 \text { and 2; } \\
\text { a } 6 \text {-point Likert scale (range, } 0 \text { - } \\
\text { 5). Higher scores on both scales } \\
\text { indicate more positive attitudes } \\
\text { toward importance of behavior }\end{array}$ \\
\hline
\end{tabular}

[Journal of Obstetric Gynecologic \& Neonatal Nursing, Vol 45, No. 4 (July-August 2016): pg. 491-501. DOI. This article is @ AWHONN, the Association of Women's Health, Obstetric and Neonatal Nurses.] and permission has been granted for this version to appear in e-Publications@Marquette. [AWHONN, the Association of Women's Health, Obstetric and Neonatal Nurses.] does not grant permission for this article to be further copied/distributed or hosted elsewhere without the express permission from [AWHONN, the Association of Women's Health, Obstetric and Neonatal Nurses.].] 
NOT THE PUBLISHED VERSION; this is the author's final, peer-reviewed manuscript. The published version may be accessed by following the link in the citation at the bottom of the page.

\begin{tabular}{|c|c|c|}
\hline Term & Conceptual Definition & $\begin{array}{l}\text { Operational Definition } \\
\text { (Derived From the LSQ) }\end{array}$ \\
\hline & & $\begin{array}{l}\text { and greater intent to use the } \\
\text { behavior. }\end{array}$ \\
\hline $\begin{array}{l}\text { Personal } \\
\text { attitudes }\end{array}$ & $\begin{array}{l}\text { The degree of } \\
\text { importance placed on the } \\
\text { PLS behaviors }\end{array}$ & Score on Part 1 of the LSQ \\
\hline $\begin{array}{l}\text { Behavioral } \\
\text { intent }\end{array}$ & $\begin{array}{l}\text { The nurse's intended use } \\
\text { of PLS behaviors in } \\
\text { practice }\end{array}$ & Score on Part 2 of the LSQ \\
\hline Subjective norm & \begin{tabular}{|l|} 
The nurse's perception of \\
the value of PLS as \\
perceived by coworkers, \\
institution, patients
\end{tabular} & Score on Part 3 of the LSQ \\
\hline $\begin{array}{l}\text { Perceived } \\
\text { behavioral } \\
\text { control }\end{array}$ & Barrier to providing PLS & \\
\hline LSQ dimensions & \multicolumn{2}{|c|}{$\begin{array}{l}\text { Conceptual definition (operational definitions = score on } \\
\text { LSQ as described above) }\end{array}$} \\
\hline $\begin{array}{l}\text { Tangible } \\
\text { Support }\end{array}$ & \multicolumn{2}{|c|}{$\begin{array}{l}\text { Performance of tasks that meet the physical needs of the } \\
\text { woman in labor }\end{array}$} \\
\hline Advocacy & \multicolumn{2}{|c|}{$\begin{array}{l}\text { Process of interpreting the woman's wishes during the } \\
\text { intrapartum period and acting on her behalf to ensure the } \\
\text { centrality of her role in decisions about care }\end{array}$} \\
\hline ES-Reassurance & \multicolumn{2}{|c|}{$\begin{array}{l}\text { The process of instilling confidence and peace of mind in } \\
\text { the laboring woman and encouraging a positive affirmation } \\
\text { and self-esteem during the process of childbirth }\end{array}$} \\
\hline $\begin{array}{l}\text { ES-Creating } \\
\text { Control, } \\
\text { Security, and } \\
\text { Comfort }\end{array}$ & \multicolumn{2}{|c|}{$\begin{array}{l}\text { The process of providing emotional support behaviors that } \\
\text { empower the woman to have control of and feel safe in the } \\
\text { environment and be involved in planning her care and pain } \\
\text { management }\end{array}$} \\
\hline $\begin{array}{l}\text { ES- Nurse } \\
\text { Caring } \\
\text { Behaviors }\end{array}$ & \multicolumn{2}{|c|}{$\begin{array}{l}\text { The processes of providing emotional support behaviors } \\
\text { that promote comfort and reassurance, show respect and } \\
\text { competency, and are helpful and respectful of the woman }\end{array}$} \\
\hline $\begin{array}{l}\text { Informational } \\
\text { Support }\end{array}$ & \multicolumn{2}{|c|}{$\begin{array}{l}\text { The process of sharing information to meet the learning } \\
\text { and knowledge needs of women in labor concerning } \\
\text { breathing, relaxation, and pushing techniques. }\end{array}$} \\
\hline
\end{tabular}

Note. Definitions in Sauls, 2000, 2004a. ES = emotional support; LSQ = Labor Support Questionnaire; PLS = professional labor support.

[Journal of Obstetric Gynecologic \& Neonatal Nursing, Vol 45, No. 4 (July-August 2016): pg. 491-501. DOI. This article is @ AWHONN, the Association of Women's Health, Obstetric and Neonatal Nurses.] and permission has been granted for this version to appear in e-Publications@Marquette. [AWHONN, the Association of Women's Health, Obstetric and Neonatal Nurses.] does not grant permission for this article to be further copied/distributed or hosted elsewhere without the express permission from [AWHONN, the Association of Women's Health, Obstetric and Neonatal Nurses.].] 
Participants also answered one question to indicate if they believed there were barriers to PLS in their institution. If they responded yes, they also answered a question to identify the presence of specific perceived barriers. Specific barriers include three perceived behavioral control items: staffing, paperwork, and lack of experience; as well as three subjective norms items: PLS not valued by my supervisor, peers, or patient. Participants were also given the option to answer a free response item to list additional barriers that were not included in the survey.

Before data collection began, Marquette University and the three hospital sites granted institutional review board approval. All labor and delivery nurses who worked in the three sites were invited to participate. The e-mail invitation to participate in the study and the survey link were sent to potential participants through the site nurse managers. To encourage participation, e-mail reminders were sent to potential study subjects at weekly intervals via the nurse manager, and printed participation requests were delivered along with snacks to each site two weeks after the survey was initially distributed. Surveys were available online via SurveyMonkey (SurveyMonkey Inc., n.d.) and remained open until no additional participation occurred over a 2 -week period.

\section{Data Analysis}

Quantitative data from this study were analyzed using SPSS version 21 for Windows. Data were examined for outliers and missing data. Four participants with half of their data missing were excluded from the final analysis. Descriptive statistics were computed for demographic characteristics. Chi-square tests and analyses of variance were performed to compare sample characteristics and LSQ results by site. Spearman correlations were calculated to evaluate the relationships among participant characteristics and variables measured on the LSQ: attitudes, intended behaviors, and barriers; t tests were performed to evaluate the association of dichotomous variables, having given birth, perception of barriers, experience with CNMs, and current schooling, to LSQ responses. Frequency counts and percentages based on the number of participants who indicated perceived barriers to PLS, including subjective norms and perceived

[Journal of Obstetric Gynecologic \& Neonatal Nursing, Vol 45, No. 4 (July-August 2016): pg. 491-501. DOI. This article is () AWHONN, the Association of Women's Health, Obstetric and Neonatal Nurses.] and permission has been granted for this version to appear in e-Publications@Marquette. [AWHONN, the Association of Women's Health, Obstetric and Neonatal Nurses.] does not grant permission for this article to be further copied/distributed or hosted elsewhere without the express permission from [AWHONN, the Association of Women's Health, Obstetric and Neonatal Nurses.].] 
behavioral control, were calculated. Significance was set at $\mathrm{p}$ less than .05 for all statistics.

\section{Results}

\section{Sample Characteristics}

Sixty of the 105 potential participants completed the LSQ and demographic surveys, for a total response rate of $57.1 \%$. Participation varied by site; $87.5 \%(n=14), 66.7 \%(n=16)$, and $49 \%(n=30)$ completed the questionnaire at the rural, suburban, and urban sites, respectively. Statistical analysis of participant characteristics showed that the subsamples were similar among the three hospital sites, with the exception of current experience with CNMs $(p<.001)$. Participants at the suburban site had significantly less experience working with CNMs. Sample demographics and comparisons are presented in Table 2.

Table 2. Participant Characteristics and Comparisons Across Sites

\begin{tabular}{|c|c|c|c|c|}
\hline \multirow[t]{2}{*}{ Characteristic } & $\begin{array}{c}\text { Site } 1 \\
\text { Rural } \\
n=14\end{array}$ & $\begin{array}{c}\text { Site } 2 \\
\text { Suburban } \\
n=16\end{array}$ & $\begin{array}{l}\text { Site } 3 \\
\text { Urban } \\
\mathbf{n}=\mathbf{3 0}\end{array}$ & \multirow[t]{2}{*}{$\mathbf{p}$} \\
\hline & n (\%) & n (\%) & n (\%) & \\
\hline \multicolumn{4}{|c|}{ Age, years } & .22 \\
\hline $20-29$ & $0(0.00)$ & $0(0.00)$ & $6(20.00)$ & \\
\hline $30-39$ & $4(28.57)$ & $3(18.75)$ & $7(23.33)$ & \\
\hline $40-49$ & $4(28.57)$ & $6(37.50)$ & $9(30.00)$ & \\
\hline $50-59$ & $4(28.57)$ & $5(31.25)$ & $8(26.67)$ & \\
\hline $60+$ & $2(14.29)$ & $2(12.5)$ & $0(0.00)$ & \\
\hline Worked with CNM & $\begin{array}{l}14 \\
(100.00)\end{array}$ & $3(18.75)$ & $30(100.00)$ & $<.01 *$ \\
\hline Have given birth & $13(92.86)$ & $16(100.00)$ & $23(76.67)$ & .06 \\
\hline \multicolumn{5}{|c|}{ Of those who have given birtha } \\
\hline Labored & $\begin{array}{l}13 \\
(100.00)\end{array}$ & $15(93.75)$ & $21(91.3)$ & .56 \\
\hline Vaginal birth & $11(84.62)$ & $14(87.50)$ & $19(82.61)$ & .92 \\
\hline Cesarean birth & $3(23.08)$ & $2(12.50)$ & $5(21.74)$ & .71 \\
\hline
\end{tabular}

[Journal of Obstetric Gynecologic \& Neonatal Nursing, Vol 45, No. 4 (July-August 2016): pg. 491-501. DOI. This article is ( AWHONN, the Association of Women's Health, Obstetric and Neonatal Nurses.] and permission has been granted for this version to appear in e-Publications@Marquette. [AWHONN, the Association of Women's Health, Obstetric and Neonatal Nurses.] does not grant permission for this article to be further copied/distributed or hosted elsewhere without the express permission from [AWHONN, the Association of Women's Health, Obstetric and Neonatal Nurses.].] 
NOT THE PUBLISHED VERSION; this is the author's final, peer-reviewed manuscript. The published version may be accessed by following the link in the citation at the bottom of the page.

\begin{tabular}{|c|c|c|c|c|}
\hline Characteristic & $\begin{array}{c}\text { Site } 1 \\
\text { Rural } \\
n=14\end{array}$ & $\begin{array}{c}\text { Site } 2 \\
\text { Suburban } \\
n=16\end{array}$ & $\begin{array}{l}\text { Site } 3 \\
\text { Urban } \\
\mathbf{n}=\mathbf{3 0}\end{array}$ & $\mathbf{p}$ \\
\hline & n (\%) & n (\%) & n (\%) & \\
\hline Epidural & $2(15.38)$ & $4(25.00)$ & $11(47.83)$ & .10 \\
\hline Analgesics (nonepidural) & $10(76.92)$ & $8(50.00)$ & $14(60.87)$ & .33 \\
\hline $\begin{array}{l}\text { Nonpharmacologic } \\
\text { measures only }\end{array}$ & $7(53.85)$ & $8(50.00)$ & $14(60.87)$ & .79 \\
\hline Years of experience & $M(S D)$ & $M(S D)$ & $M(S D)$ & \\
\hline All units & \begin{tabular}{|l|}
14.64 \\
$(8.15)$ \\
\end{tabular} & $19.06(8.82)$ & $\begin{array}{l}15.13 \\
(10.61)\end{array}$ & .35 \\
\hline On current unit (L\&D) & $\begin{array}{l}11.36 \\
(6.52)\end{array}$ & $10.63(5.25)$ & $\begin{array}{l}11.00 \\
(10.54)\end{array}$ & .97 \\
\hline
\end{tabular}

Note. CNM = certified nurse-midwife; L\&D = Labor and Delivery Unit. a Of the 52 participants who reported giving birth, 49 had more than one birth experience.

*Significant.

Participants primarily were White, had a bachelor's degree in nursing, and worked with CNMs. They had between 1 and 34 years of experience on the intrapartum unit. Participants' ages varied from 20 to over 60 years. Most participants $(86.67 \%)$ had given birth, and $94.23 \%$ had given birth more than once. Their experiences included vaginal and cesarean births and births without use of any analgesia and with systemic and epidural analgesia.

\section{LSQ Reliability}

Cronbach's alpha reliability statistics for our study are presented in Table 3. Reliability for Attitudes Toward Importance and Behavioral Intent were .93. The alpha reliability coefficients for the six individual dimensions ranged from .65 to .81. The dimensions Attitudes Toward Informational Support and Behavioral Intent Toward ES-Creating Control, Security, and Comfort were less than .70.

Table 3. Professional Labor Support: Reliability and Results of the Labor Support Questionnaire

[Journal of Obstetric Gynecologic \& Neonatal Nursing, Vol 45, No. 4 (July-August 2016): pg. 491-501. DOI. This article is (C) AWHONN, the Association of Women's Health, Obstetric and Neonatal Nurses.] and permission has been granted for this version to appear in e-Publications@Marquette. [AWHONN, the Association of Women's Health, Obstetric and Neonatal Nurses.] does not grant permission for this article to be further copied/distributed or hosted elsewhere without the express permission from [AWHONN, the Association of Women's Health, Obstetric and Neonatal Nurses.].] 
NOT THE PUBLISHED VERSION; this is the author's final, peer-reviewed manuscript. The published version may be accessed by following the link in the citation at the bottom of the page.

\begin{tabular}{|c|c|c|c|c|c|}
\hline \multirow[t]{2}{*}{$\begin{array}{l}\text { Professional Labor } \\
\text { Support Dimension }\end{array}$} & \multirow[t]{2}{*}{$\begin{array}{l}\text { Number } \\
\text { of I tems }\end{array}$} & \multicolumn{2}{|c|}{$\begin{array}{l}\text { Attitude Toward } \\
\text { I mportance }\end{array}$} & \multicolumn{2}{|c|}{ Behavioral I ntent } \\
\hline & & \begin{tabular}{|c|} 
M \\
(SD)
\end{tabular} & \begin{tabular}{|c|}
$\begin{array}{c}\text { Cronbach's } \\
\text { alpha }\end{array}$ \\
\end{tabular} & $\begin{array}{c}M \\
\text { (SD) }\end{array}$ & \begin{tabular}{|c} 
Cronbach's \\
alpha
\end{tabular} \\
\hline Total score & 27 & $\begin{array}{l}4.68 \\
(.29)\end{array}$ & .93 & $\begin{array}{l}4.54 \\
(.38)\end{array}$ & .93 \\
\hline \multicolumn{6}{|c|}{ Labor support dimensions } \\
\hline \begin{tabular}{|l} 
Emotional Support- \\
Nurse Caring \\
Behaviors \\
\end{tabular} & 3 & $\begin{array}{l}4.85 \\
(.31)\end{array}$ & .76 & $\begin{array}{l}4.77 \\
(.39)\end{array}$ & .73 \\
\hline Informational Support & 3 & $\begin{array}{l}4.81 \\
(.32)\end{array}$ & .65 & $\begin{array}{l}4.71 \\
(.40)\end{array}$ & .73 \\
\hline \begin{tabular}{|l|} 
Emotional Support- \\
Creating Control, \\
Security, and Comfort \\
\end{tabular} & 5 & $\begin{array}{l}4.76 \\
(.32)\end{array}$ & .72 & $\begin{array}{l}4.61 \\
(.39)\end{array}$ & .67 \\
\hline \begin{tabular}{|l|} 
Emotional Support- \\
Reassurance
\end{tabular} & 5 & $\begin{array}{l}4.72 \\
(.36)\end{array}$ & .73 & $\begin{array}{l}4.64 \\
(.40)\end{array}$ & .73 \\
\hline Advocacy & 5 & $\begin{array}{l}4.71 \\
(.38)\end{array}$ & .81 & $\begin{array}{l}4.58 \\
(.44)\end{array}$ & .77 \\
\hline Tangible Support & 5 & $\begin{array}{l}4.41 \\
(.47)\end{array}$ & .71 & $\begin{array}{l}4.17 \\
(.55)\end{array}$ & .75 \\
\hline
\end{tabular}

\section{Comparison of Results by Site}

There were no significant differences among sites for Attitudes Toward Importance $(p=.63)$ or for Behavioral Intent $(p=.69)$ for PLS behaviors. Because of the small sample sizes, homogeneity in sample characteristics, and survey responses between sites, the three groups were combined for the remaining statistical analyses to take advantage of the larger sample size (Polit, 2010).

\section{Attitudes and Behavioral Intent for PLS}

Repeated measures analysis with simple contrast was performed to evaluate participants' ratings of the PLS dimensions. ES-Nurse Caring Behaviors was rated significantly higher than the other dimensions for Attitudes Toward Importance $\left(F_{(5,295)}=32.39\right)$ and Behavioral Intent $\left(F_{(5,295)}=40.87\right)$. The LSQ results are presented in Table 3 . Means of all dimension scores were greater than 4, which indicated high importance of and intent to use PLS behaviors. 


\section{Barriers to PLS: Perceived Behavioral Control and Subjective Norms}

Most participants indicated that they perceived barriers to PLS in their institutions ( $n=41 ; 68.3 \%$ ). Those who responded that they perceived barriers to practice identified paperwork ( $n=34 ; 82.92 \%$ ) and staffing ( $n=31 ; 75.61 \%$ ) as barriers to PLS. They also answered that subjective norms such as supportive care not valued by women ( $n=10 ; 24.39 \%$ ) and supportive care not valued by peers ( $n=5$; $12.2 \%$ ) represented barriers to PLS. Eighteen participants provided additional comments and elaborated on barriers to PLS. These included staffing $(n=4)$, documentation $(n=5)$, physicians $(n=3)$, epidurals $(n=4)$, doulas $(n=3)$, and birth plans $(n=2)$. Six participants documented subjective norms that they believed limited PLS: (a) the perception that labor support was not valued by charge nurses and (b) that some peers and patient-support persons devalued the time spent in the provision of PLS.

Relationships Among Attitudes, Behaviors, Barriers, and Nurse Characteristics

The LSQ responses were not significantly associated with participants' having given birth, perception of barriers, experience with CNMs, or current schooling. Spearman correlations were performed on the aggregate data to evaluate the relationships between participant characteristics and variables measured on the LSQ: attitudes, intended behaviors, and barriers (see Table 4). As expected, dimension correlations were all significant ( range $=.45$ to $.78, p<.01$ ). The relationships among attitudes, intended behaviors, and barriers, and nurse and unit characteristics, were primarily related to participants' own birth experiences and the length of time working on the unit. For the entire sample $(n=60)$, the length of time working on the unit was significantly correlated with attitudes toward the importance of PLS dimensions ES-Reassurance and Creating Control, Security, and Comfort as well as the importance of Informational Support.

Personal birth experiences and length of time working on the current intrapartum unit were significantly correlated with participants' attitudes about and intent to provide professional labor support. [Journal of Obstetric Gynecologic \& Neonatal Nursing, Vol 45, No. 4 (July-August 2016): pg. 491-501. DOI. This article is @ AWHONN, the Association of Women's Health, Obstetric and Neonatal Nurses.] and permission has been granted for this version to appear in e-Publications@Marquette. [AWHONN, the Association of Women's Health, Obstetric and Neonatal Nurses.] does not grant permission for this article to be further copied/distributed or hosted elsewhere without the express permission from [AWHONN, the Association of Women's Health, Obstetric and Neonatal Nurses.].] 
Table 4. Significant Spearman Correlations

\begin{tabular}{|c|c|c|c|c|c|}
\hline \multicolumn{2}{|c|}{$\begin{array}{c}\text { Analgesic } \\
\text { (Nonepidural) }\end{array}$} & \multicolumn{2}{|c|}{$\begin{array}{c}\text { Tangible Support } \\
\text { Intention }\end{array}$} & \multicolumn{2}{|c|}{$\begin{array}{l}\text { Length of Time Working } \\
\text { on Current Unit }\end{array}$} \\
\hline $\begin{array}{l}\text { Tangible } \\
\text { Support: } \\
\text { Attitude } \\
\end{array}$ & $.33^{*}$ & Labor \# & \begin{tabular}{|l|}
$.31^{*}$ \\
\end{tabular} & $\begin{array}{l}\text { Emotional Support- } \\
\text { Reassurance: Attitude }\end{array}$ & $.29 *$ \\
\hline $\begin{array}{l}\text { Tangible } \\
\text { Support: } \\
\text { Intention }\end{array}$ & $38^{* *}$ & Vaginal birth & $.40^{* *}$ & $\begin{array}{l}\text { Emotional Support- } \\
\text { Creating Control, } \\
\text { Security, and Comfort: } \\
\text { Attitude }\end{array}$ & $31 *$ \\
\hline $\begin{array}{l}\text { Advocacy: } \\
\text { Attitude }\end{array}$ & $.35^{*}$ & Analgesics & $.38^{*}$ & $\begin{array}{l}\text { Informational Support: } \\
\text { Attitude }\end{array}$ & 27 \\
\hline $\begin{array}{l}\text { Advocacy: } \\
\text { Intention }\end{array}$ & $29 *$ & $\begin{array}{l}\text { Nonpharmacologic } \\
\text { measures }\end{array}$ & $.46^{* *}$ & & \\
\hline $\begin{array}{l}\text { Informational } \\
\text { Support: } \\
\text { Attitude }\end{array}$ & $.32 *$ & & & & \\
\hline
\end{tabular}

$* p<.05 . * * p<.01$.

For the 52 participants who had given birth, the number of times participants used analgesics during their own labors was positively correlated with Attitude Toward Importance and Behavioral Intent toward the Advocacy and Tangible Support PLS dimensions. Additionally, the use of analgesics was positively correlated with attitude toward the importance of Informational Support.

\section{Discussion}

The findings of our study implied that the participants' personal birth experiences were associated with their attitudes toward the importance of and their intended use of PLS behaviors. To our knowledge, this relationship has not previously been reported in the literature. The more births participants had for which they used analgesics (nonepidural), the higher the Importance and Behavioral Intent responses given to PLS Dimensions Tangible Support and Advocacy, and the higher the importance of I nformational Support. In fact, intended use of one PLS dimension, Tangible Support, was associated with several personal birth experiences, including number of labors and vaginal births and use of nonpharmacologic measures only or analgesics (nonepidural) for pain management.

[Journal of Obstetric Gynecologic \& Neonatal Nursing, Vol 45, No. 4 (July-August 2016): pg. 491-501. DOI. This article is () AWHONN, the Association of Women's Health, Obstetric and Neonatal Nurses.] and permission has been granted for this version to appear in e-Publications@Marquette. [AWHONN, the Association of Women's Health, Obstetric and Neonatal Nurses.] does not grant permission for this article to be further copied/distributed or hosted elsewhere without the express permission from [AWHONN, the Association of Women's Health, Obstetric and Neonatal Nurses.].] 
Attitudes and behavioral intent toward PLS were correlated with the participants' own personal birth experiences and length of time working on the current intrapartum unit. This finding was consistent with the Theory of Planned Behavior (Ajzen, 2002), which identified the influence of background factors, including past experiences, on attitudes, perceived subjective norms, and perceived behavioral control. Together, they influenced study participants' attitudes toward the importance of and intent to provide PLS. In addition, ratings on the individual dimensions were consistent for both attitudes and intended behaviors, as previously noted. It would be expected that dimensions with high attitude ratings also would have high intent-to-act ratings.

Radin et al. (1993) documented cesarean rates for individual nurses and reported that differences in rates among the nurses could not be explained by other factors. Individual nurse differences may have been influential, but they were not evaluated. Because the personal birth experiences and length of employment of nurses who participated in our study were correlated with attitudes and intended PLS behaviors, this finding deserves more study. Ideally, nurses should provide labor support based on the best evidence and the individual needs of the laboring woman; however, participants in our study may be more likely to provide care for laboring women based on their own personal labor experiences.

Emotional Support-Nurse Caring Behaviors, which include provision of reassurance and praise and demonstration of empathy and care, were most important to participants and were usually included as part of PLS. Miltner (2002) reported observations of intrapartum nursing care that reflected similar values. More than half of the interventions observed in Miltner's study targeted the provision of ES, including praise and reassurance. In addition, the longer participants worked on the current intrapartum unit, the higher the importance and use of the other ES dimensions, ES-Reassurance and ES-Creating Control, Comfort, and Security, as well as Informational Support.

Barriers to PLS included perceived behavioral control factors such as staffing, documentation, and high technology interventions. Lack of staffing was a common PLS barrier identified in previous studies (Carlton et al., 2009; Davies \& Hodnett, 2002; Sleutel et al., [Journal of Obstetric Gynecologic \& Neonatal Nursing, Vol 45, No. 4 (July-August 2016): pg. 491-501. DOI. This article is (c) AWHONN, the Association of Women's Health, Obstetric and Neonatal Nurses.] and permission has been granted for this version to appear in e-Publications@Marquette. [AWHONN, the Association of Women's Health, Obstetric and Neonatal Nurses.] does not grant permission for this article to be further copied/distributed or hosted elsewhere without the express permission from [AWHONN, the Association of Women's Health, Obstetric and Neonatal Nurses.].] 
2007). Sleutel et al. (2007) also reported documentation as a barrier to PLS. Interventions such as epidurals similarly were barriers to labor support. Sleutel et al. (2007) reported that high technology interventions such as epidurals were the most frequent barriers to labor support and described the interference in nursing care that resulted. Hodnett et al. (2002) stated that nurses' efforts to provide continuous labor support still may not lead to improved outcomes in high-intervention environments but that women would choose continuous labor support if given the option. Nurses may become preoccupied with attending to technology, documenting, and monitoring, rather than providing women with labor support and comfort (Hodnett et al., 2013). Previously it was found that nurses' attention was directed toward the fetal monitor rather than on the provision of labor support, especially when the intrapartum unit was very busy (Angus, Hodnett, \& O'Brien-Pallas, 2003). Now in most settings, the electronic health record also is a part of the same electronic monitoring system. The relationship of electronic health record charting as a potential barrier to PLS deserves more attention.

Subjective norms, that is, beliefs that intrapartum care was not valued by patients or peers, doulas, and families, also were barriers to PLS, similar to the findings of Payant et al. (2008). Participants in our study placed less importance on and had a lower intent to use PLS for women who received epidural analgesia. Payant and associates reported that nurses who care for laboring women who have an epidural may be expected by other staff not to stay in the patients' rooms but instead to help other nurses with their responsibilities or cover patients so that nurses can take breaks. In fact, Sleutel et al. (2007) reported that peers criticized other nurses for spending time in the patients' rooms.

Previous investigators have identified the importance of subjective norms and perceived behavioral control as contributing to nurses' behavioral intent to provide PLS (Sauls, 2007). Our participants identified staffing and documentation as barriers and lack of valuing labor support by peers or patients as subjective norms that influenced PLS. In our study, perception of barriers was not significantly correlated with attitudes or behavioral intent on the PLS dimensions. Responding yes that barriers are present in the current AWHONN, the Association of Women's Health, Obstetric and Neonatal Nurses.] and permission has been granted for this version to appear in e-Publications@Marquette. [AWHONN, the Association of Women's Health, Obstetric and Neonatal Nurses.] does not grant permission for this article to be further copied/distributed or hosted elsewhere without the express permission from [AWHONN, the Association of Women's Health, Obstetric and Neonatal Nurses.].] 
worksite was negatively correlated with all PLS dimensions for importance of and intent to use the behaviors. Participants who reported barriers to PLS gave lower ratings to importance of and intent to use PLS behaviors, although the relationships were not significant. Although these trends are consistent with the results of previous studies, the lack of statistically significant findings was unexpected because 41 (68.3\%) participants identified barriers to PLS. This finding may be attributable to the small sample size in our study.

\section{Implications for Nursing Practice}

Intrapartum nurses would benefit from an examination of their own personal birth experiences for potential influence on how they provide labor support. They should develop and maintain awareness of evidence-based practices to support or enhance their intrapartum nursing care. For example, nurses' priority goal of optimal outcomes for women and their newborns may be best accomplished through interventions to maintain continuous presence during PLS. Continuous presence is a key element to improve outcomes ( and is helpful for laboring women (Bowers, 2002; Corbett \& Callister, 2000). In addition, the provision of more labor and birth experiences for novice nurses and nursing students may enhance or hasten the positive influence of experience on attitudes and intended PLS behaviors.

The influence of personal factors, including birth experiences, on labor care is an important finding that deserves further attention, exploration, and study.

\section{Suggestions for Future Research}

Our study was another step in understanding PLS. The findings provide increased knowledge of intrapartum nurses' attitudes, intended behaviors, and perceptions of barriers to the provision of PLS. The influence of personal factors, including birth experiences, on labor care is a unique and important finding that deserves further attention, exploration, and study. Nurse researchers might further explore the relationship of personal birth experiences to intrapartum nurses' labor support attitudes and actual behaviors. Evaluation of nurses' decision

[Journal of Obstetric Gynecologic \& Neonatal Nursing, Vol 45, No. 4 (July-August 2016): pg. 491-501. DOI. This article is (C) AWHONN, the Association of Women's Health, Obstetric and Neonatal Nurses.] and permission has been granted for this version to appear in e-Publications@Marquette. [AWHONN, the Association of Women's Health, Obstetric and Neonatal Nurses.] does not grant permission for this article to be further copied/distributed or hosted elsewhere without the express permission from [AWHONN, the Association of Women's Health, Obstetric and Neonatal Nurses.].] 
making about labor support, in a manner that would reveal strategies used and information considered with attention to intrapartum outcomes, also deserves further study. New tools that evaluate nurses' attitudes about labor and birth (Levine \& Lowe, 2015) may be used along with behavioral reports, observations, and outcomes to identify important factors that influence outcomes. In addition, evaluation of nurses' knowledge and attitudes about current evidence about the value of PLS may reveal possible explanations for the care they provide. Qualitative methods may be ideal to more deeply understand nurses' PLS attitudes and behaviors. For example, interviews may optimally identify attitudes that can be verified by direct observation. This type of mixed-method study may also elucidate the implications of epidural use on PLS.

\section{Strengths and Limitations}

A strength of this study was the use of the LSQ with evidence for the tool's validity and reliability (Sauls, 2000, 2004a). The LSQ is based on the Theory of Planned Behavior (Ajzen, 2002; Ajzen \& Fishbein, 1980), the theoretical foundation for the study. The administration of the survey via SurveyMonkey ensured a uniform online delivery system. Our study lacked statistical power (a priori power analysis was not computed) because of the exploratory and descriptive design. Although the study sites were chosen to maximize diversity, there were no significant differences in sample demographics or survey responses among the sites, threatening statistical conclusion validity and limiting external validity (Polit, 2010). The cross-sectional design limited participants' participation to a single point in time (Hulley, Cummings, Browner, Grady, \& Newman, 2007). Most participants completed the survey during work hours; therefore, responses may vary based on current work environment. The scores on the PLS dimensions and their associated behaviors indicated that they were all of high importance and almost always used, possibly because of a ceiling effect, which would minimize differences between groups. The findings related to the dimensions Attitude Toward Informational Support and Intended Use of ES-Creating Control, Security, and Comfort are limited by low Cronbach alphas $(<.70)$ on these subscales.

[Journal of Obstetric Gynecologic \& Neonatal Nursing, Vol 45, No. 4 (July-August 2016): pg. 491-501. DOI. This article is @ AWHONN, the Association of Women's Health, Obstetric and Neonatal Nurses.] and permission has been granted for this version to appear in e-Publications@Marquette. [AWHONN, the Association of Women's Health, Obstetric and Neonatal Nurses.] does not grant permission for this article to be further copied/distributed or hosted elsewhere without the express permission from [AWHONN, the Association of Women's Health, Obstetric and Neonatal Nurses.].] 
NOT THE PUBLISHED VERSION; this is the author's final, peer-reviewed manuscript. The published version may be accessed by following the link in the citation at the bottom of the page.

\section{Conclusion}

We found that intrapartum nurses' own birth experiences influenced their attitudes toward and intended behaviors for labor support. This insight may lead to a better understanding of individual influences on PLS. Recognition of factors that influence PLS, and the importance of evidence-based practice, may lead to practice changes to promote healthy birth outcomes.

\section{References:}

Ajzen, 2002 I. Ajzen Perceived behavioral control, self-efficacy, locus of control, and the theory of planned behavior J ournal of Applied Social Psychology, 32 (4) (2002), pp. 665-683, 10.1111/j.15591816.2002.tb00236.x

Ajzen and Fishbein, 1980 I. Ajzen, M. Fishbein Understanding attitudes and predicting social behavior Prentice Hall, Englewood Cliffs, NJ (1980)

Angus et al., $2003 \mathrm{~J}$. Angus, E. Hodnett, L. O'Brien-Pallas I mplementing evidence-based nursing practice: $A$ tale of two intrapartum nursing units Nursing Inquiry, 10 (2003), pp. 218-228

Barrett and Stark, 2010 S.J. Barrett, M.A. Stark Factors associated with

labor support behaviors of nurses The J ournal of Perinatal

Education, 19 (1) (2010), pp. 12-18, 10.1624/105812410X481528

Bowers, 2002 B. Bowers Mothers' experiences of labor support:

Exploration of qualitative research Journal of Obstetric,

Gynecologic, \& Neonatal Nursing, 31 (6) (2002), pp. 742-752,

$10.1177 / 0884217502239218$

Campbell et al., 2006 D.A. Campbell, M.F. Lake, M. Falk, J.R. Backstrand

A randomized control trial of continuous support in labor by a lay doula J ournal of Obstetric, Gynecologic, \& Neonatal Nursing, 35

(4) (2006), pp. 456-464, 10.1111/1.1552-6909.2006.00067.x

Carlton et al., 2009 T. Carlton, L.C. Callister, G. Christiaens, D. Walker

Nurses' perceptions of caring for childbearing women in nursemanaged birthing units Maternal Child Nurse, 34 (1) (2009), pp.

50-56, 10.1097/01. NMC.0000343866.95108

Corbett and Callister, 2000 C.A. Corbett, L.C. Callister Nursing support

during labor Clinical Nursing Research, 9 (1) (2000), pp. 70-83,

$10.1177 / 105477380000900106$

Davies and Hodnett, 2002 B.L. Davies, E. Hodnett Labor support: Nurses'

self-efficacy and views about factors influencing

implementation J ournal of Obstetric, Gynecologic, \& Neonatal

[Journal of Obstetric Gynecologic \& Neonatal Nursing, Vol 45, No. 4 (July-August 2016): pg. 491-501. DOI. This article is @ AWHONN, the Association of Women's Health, Obstetric and Neonatal Nurses.] and permission has been granted for this version to appear in e-Publications@Marquette. [AWHONN, the Association of Women's Health, Obstetric and Neonatal Nurses.] does not grant permission for this article to be further copied/distributed or hosted elsewhere without the express permission from [AWHONN, the Association of Women's Health, Obstetric and Neonatal Nurses.].] 
NOT THE PUBLISHED VERSION; this is the author's final, peer-reviewed manuscript. The published version may be accessed by following the link in the citation at the bottom of the page.

Nursing, 31 (1) (2002), pp. 48-56, 10.1111/j.1552-

6909.2002.tb00022.x

Gagnon and Waghorn, 1999 A.J. Gagnon, K. Waghorn One-to-one nurse

labor support of nulliparous women stimulated with oxytocin

Journal of Obstetric, Gynecologic, \& Neonatal Nursing, 28 (1999), pp.

371-376, 10.1111/j.1552-6909.1999.tb02005.x

Gagnon et al., 1997 A.J. Gagnon, K. Waghorn, C. Covell A randomized trial

of one-to-one nurse support of women in labor Birth, 24 (2)

(1997), pp. 71-77, 10.1111/j.1523-236X.1997.00071.pp.x

Hodnett et al., 2013 E.D. Hodnett, S. Gates, G.J . Hofmeyr, C. Sakala

Continuous support for women during childbirth Cochrane

Database of Systematic Reviews, 2013 (7) (2013), p. CD003766,

10.1002/14651858. CD003766.pub5

Hodnett et al., 2002 E.D. Hodnett, N.K. Lowe, M.E. Hannah, A.R. Willan, B.

Stevens, J.A. Weston, ..., R. Stremler Effectiveness of nurses as

providers of birth labor support in North American hospitals: A

randomized controlled trial J ournal of the American Medical

Association, 288 (11) (2002), pp. 1373-1381,

10.1001/jama.288.11.1373

Hodnett and Osborn, 1989 E.D. Hodnett, R.W. Osborn Effects of continuous

intrapartum professional support on childbirth outcomes

Research in Nursing and Health, 12 (5) (1989), pp. 289-297,

10.1002/nur.4770120504

Hodnett et al., 2008 E.D. Hodnett, R. Stremler, A.R. Willan, J.A. Weston, N.K. Lowe, K.R. Simpson, ..., A. Gafni Effect on birth outcomes of a formalized approach to care in hospital labour assessment units: I nternational, randomized controlled trial British Medical Journal, 337 (2008), pp. 1-8, 10.1136/bmja1021

Hulley et al., 2007 S.B. Hulley, S.R. Cummings, W.S. Browner, D.G. Grady,

T.B. Newman Designing clinical research (3rd ed.), Wolters Kluwer,

Philadelphia (2007)

Kashanian et al., 2010 M. Kashanian, F. Javadi, M. M. Haghighi Effect of

continuous support during labor on duration of labor and rate

of cesarean delivery International J ournal of Gynecology and

Obstetrics, 109 (2010), pp. 198-200, 10.1016/j.ijgo.2009.11.028

Kennell et al., $1991 \mathrm{~J}$. Kennell, M. Klaus, S. McGrath, S. Robertson, C. Hinkley

Continuous emotional support during labor in a US hospital

Journal of the American Medical Association, 265 (17) (1991), pp.

2197-2201, 10.1001/jama.199.03460170051032

Klaus et al., 1986 M. Klaus, J. Kennell, S.S. Robertson, R. Sosa Effects of social support during parturition on maternal and infant morbidity British J ournal of Medicine, 293 (1986), pp. 585-587, $10.1136 /$ bmj.293.6547.585

[Journal of Obstetric Gynecologic \& Neonatal Nursing, Vol 45, No. 4 (July-August 2016): pg. 491-501. DOI. This article is (C) AWHONN, the Association of Women's Health, Obstetric and Neonatal Nurses.] and permission has been granted for this version to appear in e-Publications@Marquette. [AWHONN, the Association of Women's Health, Obstetric and Neonatal Nurses.] does not grant permission for this article to be further copied/distributed or hosted elsewhere without the express permission from [AWHONN, the Association of Women's Health, Obstetric and Neonatal Nurses.].] 
NOT THE PUBLISHED VERSION; this is the author's final, peer-reviewed manuscript. The published version may be accessed by following the link in the citation at the bottom of the page.

Langer et al., 1998 A. Langer, L. Campero, C. Garcia, S. Reynoso Effects of psychosocial support during labour and childbirth on breastfeeding, medical interventions and mothers well-being in a Mexican public hospital: A randomized controlled trial British Journal of Obstetrics and Gynecology, 105 (10) (1998), pp. 10561063, 10.1111/j.1471-0528.1998.tb09936.x

Levine and Lowe, 2015 M.S. Levine, N.K. Lowe Measuring nurse attitudes about childbirth: Revision and pilot testing of the Nurse Attitudes and Beliefs Questionnaire Journal of Nursing Measurement, 23 (2) (2015), pp. 287-301, 10.1891/10613749.23.2.287

MacDorman et al., 2014 M.F. MacDorman, T.J. Mathews, E. Declercq Trends in out-of-hospital births in the United States, 1990- 2012 (NCHS Data Brief, 144) National Center for Health Statistics, Hyattsville, MD (2014)

Madi et al., 1999 B.C. Madi, J. Sandall, R. Bennett, C. MacLeod Effects of female relative support in labor: $A$ randomized controlled trial Birth, 26 (1) (1999), pp. 4-8, 10.1046/j.1523-536x.1999.00004.x McGrath and Kennell, 2008 S.K. McGrath, J.H. Kennell A randomized controlled trial of continuous labor support for middle-class couples: Effect on cesarean delivery rates Birth, 35 (2) (2008), pp. 92-97, 10.1111/j.1523-536X.2008.00221.X

Miltner, 2002 R.S. Miltner More than support: Nursing interventions provided to women in labor J ournal of Obstetric, Gynecologic, \& Neonatal Nursing, 31 (6) (2002), pp. 753-761, $10.1177 / 0884217502239214$

Morhason-Bello et al., 2009 I.O. Morhason-Bello, B.O. Adedokun, O.A.

Ajengbede, O. Olayemi, A. Oladokun, A.O. Fabamwo Assessment of the effect of psychosocial support during childbirth in I badan, southwest Nigeria: A randomized controlled trial Australian and New Zealand J ournal of Obstetrics and Gynaecology, 49 (2009), pp. 145-150, 10.1111/j.1479-828X.2009.00983.x Payant et al., 2008 L. Payant, B. Davies, I.D. Graham, W.E. Peterson, J . Clinch Nurses' intentions to provide continuous labor support to women J ournal of Obstetric, Gynecologic, \& Neonatal Nursing, 37 (4) (2008), pp. 405-414, 10.1111/j.1552-6909.2008.00257.x

Polit, 2010 D.F. Polit Statistics and data analysis for nursing research (2nd ed.), Pearson, Upper Saddle River, NJ (2010)

Radin et al., 1993 T. Radin, J. Harmon, D. Hanson Nurses' care during labor: I ts effect on the cesarean birth rate of healthy, nulliparous women Birth, 20 (1) (1993), pp. 14-22, 10.1111/j.1523536X.1993.tb00174.x

[Journal of Obstetric Gynecologic \& Neonatal Nursing, Vol 45, No. 4 (July-August 2016): pg. 491-501. DOI. This article is (C) AWHONN, the Association of Women's Health, Obstetric and Neonatal Nurses.] and permission has been granted for this version to appear in e-Publications@Marquette. [AWHONN, the Association of Women's Health, Obstetric and Neonatal Nurses.] does not grant permission for this article to be further copied/distributed or hosted elsewhere without the express permission from [AWHONN, the Association of Women's Health, Obstetric and Neonatal Nurses.].] 
NOT THE PUBLISHED VERSION; this is the author's final, peer-reviewed manuscript. The published version may be accessed by following the link in the citation at the bottom of the page.

Sauls, 2000 D.J. Sauls Measurement of perceptions of intrapartum nurses regarding professional labor support (Doctoral dissertation) (2000) Retrieved from ProQuest, UMI Dissertations Publishing (UMI 9993963)

Sauls, 2004a D.J. Sauls Labor support manual Unpublished manuscript (2004)

Sauls, 2004b D.J. Sauls The Labor Support Questionnaire: Development and psychometric analysis J ournal of Nursing Measurement, 12 (2) (2004), pp. 123-132, 10.1891/jnum.2004.12.2.123

Sauls, 2006 D.J. Sauls Dimensions of professional labor support for intrapartum practice J ournal of Nursing Scholarship, 38 (1) (2006), pp. 36-41, 10.1111/j.1547-5069.2003.0075.x

Sauls, 2007 D.J. Sauls Nurses' attitudes toward provision of care and related health outcomes Nursing Research, 56 (2) (2007), pp. 117123

Sleutel, 2000 M. Sleutel I ntrapartum nursing care: A case study of supportive interventions and ethical conflicts Birth, 27 (1) (2000), pp. 38-45, 10.1046/j.1523-536x.2000.00038.x

Sleutel et al., 2007 M. Sleutel, S. Schultz, K. Wyble Nurses' views of factors that help and hinder their intrapartum care J ournal of Obstetric, Gynecologic, \& Neonatal Nursing, 36 (3) (2007), pp. 203211, 10.1111/j.1552-6909.2007.00146.x SurveyMonkey, Inc. SurveyMonkey, Inc. [Computer software]. (n.d.). Palo Alto, CA. Retrieved from www.surveymonkey.com

Trueba et al., 2000 G. Trueba, C. Contreras, M.T. Velazco, E.G. Lara Alternative strategy to decrease cesarean section: Support by doulas during labor J ournal of Perinatal Education, 9 (2) (2000), pp. $8-13, \underline{10.1624 / 105812400 \times 87608}$

[Journal of Obstetric Gynecologic \& Neonatal Nursing, Vol 45, No. 4 (July-August 2016): pg. 491-501. DOI. This article is @ AWHONN, the Association of Women's Health, Obstetric and Neonatal Nurses.] and permission has been granted for this version to appear in e-Publications@Marquette. [AWHONN, the Association of Women's Health, Obstetric and Neonatal Nurses.] does not grant permission for this article to be further copied/distributed or hosted elsewhere without the express permission from [AWHONN, the Association of Women's Health, Obstetric and Neonatal Nurses.].] 